\title{
Impact of a Jet A-1/HEFA blend on the performance and emission characteristics of a miniature turbojet engine
}

\author{
B. Gawron ${ }^{1}$ T. Białecki ${ }^{1}$
}

Received: 13 April 2017/Revised: 24 July 2017/ Accepted: 5 September 2017 / Published online: 13 September 2017

(C) The Author(s) 2017. This article is an open access publication

\begin{abstract}
It is forecast that in the future, alternative fuels derived from non-petroleum sources will become the basic propellant for turbine aircraft engines. Currently, five types of aviation turbine fuel containing synthesized hydrocarbons are certified and accepted, and allow adding a maximum of $50 \%$ of synthetic component to conventional fuel. The experimental performance and the emission characteristics of a turbojet engine were investigated in this paper. The studies were conducted with the use of a miniature turbojet engine, which is the main component of a laboratory test rig. The test rig is an interesting solution for engine research, due to the fact that studies concerning fullscale aircraft engines are very complex and expensive. The literature of the subject contains many papers using smallscale turbojet engines for testing alternative fuels. However, most of them concern components of fuels, e.g. biodiesel, butanol, which do not have direct application in aviation. Two different fuel samples, a conventional Jet A-1 fuel and a blend of $48 \%$ synthesized paraffinic kerosene from hydroprocessed esters and fatty acids process with Jet A-1 were tested. This process is one of the routes of producing alternative fuel for aviation, approved by ASTM standard. The test rig studies were performed according to a specific profile of engine test, which models different modes of a turbojet engine's operation. The obtained results are compared in relation to the results for neat Jet A-1 fuel and then discussed.
\end{abstract}

Editorial responsibility: Necip Atar.

\footnotetext{
B. Gawron

bartosz.gawron@itwl.pl

1 Division for Fuels and Lubricants, Air Force Institute of Technology, 01-494 Warsaw, Poland
}

Keywords Biofuels - Combustion process - Effect on environmental $\cdot$ Synthesized paraffinic kerosene $\cdot$ Turbine engine

\section{Introduction}

The field of researching and testing new fuels/biofuels for air transport is a globally important issue. This is confirmed by the recently undertaken research programmes, e.g. ITAKA-Initiative Towards Sustainable Kerosene for Aviation (Velarde 2015), BFSJ-Production of a fully synthetic jet fuel from timber and other biomass, BIOREFLY - Industrial scale demonstration biorefinery on ligninbased aviation fuel (Buffi et al. 2017). The aim of these programmes is to promote the use of alternative jet fuels derived from non-conventional sources.

Environmental effects of emissions from aircraft engine were considered in paper (Braun-Unkhoff et al. 2017). Generated emission from aircraft industry has not only a negatively effect on climate and air quality but also human health. One of major methods of harmful combustion products emissions reduction is implementation to the fossil fuel various components, including biocomponents and biofuels (Chishty et al. 2011; Şöhret et al. 2015).

The procedure of approving new fuels for use in turbojet aircraft engines is defined in the ASTM D4054-14 (1981). It is a very complex process, starting with laboratory research in the field of physical and chemical fuel properties and ending with tests on full-scale turbine engine. Opportunities and challenges in the development of alternative fuels for aviation were shown by Hari et al. 2015 . Scientific and technological advances related to the existing pathways to produce biojet and future implementation 
of a sustainable production chain for renewable aviation fuel were reviewed by Gutierrez-Antonio et al. 2017.

A review of the most important achievements of the last 10 years in the scope of studies conducted on alternative fuels for aircraft turbine engines was presented by Zhang et al. 2016. Many experiments executed both, on different types of real aircraft engines, as well as with the use of different alternative fuels were presented in the field of engine studies. Worth noting is the fact that the authors referred to the results of the research (Badami et al. 2014), executed on a small-scale turbojet engine.

Experimental tests on full-scale turbojet engines are very complex and expensive. For this reason, the possibility to conduct tests with the use of small-scale engines is an interesting solution. Such engines are used not only in the scientific and research works (Badami et al. 2013; Benini and Giacometti 2007; Gawron and Białecki 2015, 2016; Nkoi et al. 2013), but also used as propulsion for aerial targets, unmanned aerial vehicles (Andrei et al. 2016) and drones (Dutczak 2016). Studies on small-scale engines will not replace the need to perform tests on large engine but can, however, be an element, which supplements and support the research process. Due to a lower fuel demand in small-scale engine tests, investigations may be executed in a much broader range, e.g. by testing fuels from experimental production plants, which are often characterized by limited quantities. Works in the scope of creating numerical models, which simulate the processes in real aeroengines (Gaspar and Sousa 2016), and using exergy and exergoeconomics analyses are also conducted (Coban et al. 2017).

Numerous publications can be found in the literature (Ali and Nour 2017; Badami et al. 2014; Baranski et al. 2011; Canteenwalla et al. 2016; Cavarzere et al. 2014; Chiaramonti et al. 2013; Chiariello et al. 2014; Chishty et al. 2011; Gawron et al. 2016; Habib et al. 2010; Hoxie and Anderson 2017; Ibrahim et al. 2013; Mendez et al. 2014), which are associated with testing different fuels with the use of small-scale turbine engines. It is worth emphasizing that currently fuels containing synthesized hydrocarbons obtained through five specific paths described in ASTM D7566-16 (2009) are approved for direct use as synthetic blending components (up to 50\%) in aviation turbine fuels. Most papers mentioned above, concern studies with the use of fuels (e.g. biodiesel, butanol), which do not have direct application for aviation. However, they can be an alternative power source for gas turbine engines for applications other than aviation. Only the following papers (Badami et al. 2014; Baranski et al. 2011; Canteenwalla et al. 2016; Chishty et al. 2011) concern the tests on small-scale engines in the scope of fuels: gas to liquid (GTL), hydroprocessed renewable jet (HRJ), synthetic aromatic kerosene (SAK), which may be used in aircraft turbine engines.

A conclusion of the literature review is that conducting initial studies in the field of alternative jet fuels with the use of a small-scale turbine engine is fully justified. Such test rigs are currently widely used in test studies regarding fuels, mainly biodiesel, in the scope of stationary gas turbine engines.

This study aims to investigate the performance and emission characteristics of a miniature turbojet engine fed with jet fuel with synthesized paraffinic kerosene (SPK) from hydroprocessed esters and fatty acids (HEFA). It is one of the production paths for alternative aviation turbine fuel approved by the ASTM D7566-16 (2009). The biofuel results were compared with the results obtained for neat Jet A-1 fuel in terms of different engine operating modes, according to a specific methodology.

This research work was carried out in December 2016 at Air Force Institute of Technology, Division for Fuels and Lubricants, Warsaw, Poland.

\section{Materials and methods}

\section{Description of the test rig}

The experimental activity is carried out by using a specialized test rig-Miniature Jet Engine Test Rig (MiniJETRig). The main element of the rig is a miniature turbojet engine of the GTM 140 series, which operates in the range of $33000-120000 \mathrm{rpm}$ and its maximum thrust is $140 \mathrm{~N}$. The engine has a single-stage radial compressor driven by a single-stage axial turbine and an annular combustion chamber with a set of vaporizer tubes.

The structure of the test rig, together with a description of its components, was presented in the following paper (Gawron and Białecki 2015). The data regarding the technical specification of the miniature turbojet engine, the sensors used to measure the basic operating parameters of the engine and the equipment for measuring gas emissions were described by Gawron and Białecki 2016 and Gawron et al. 2016. The harmful components of exhaust gases were measured using a portable exhaust analyser. The gas sample probe was positioned in the centre of the exhaust stream in the end section of the engine exhaust system.

Engine can be started up in two ways; electrically, via an automatic electric starter, or pneumatically, with the help of compressed air. Mass flow rate measurement on the engine inlet is possible in the second case. Then, it is necessary to use a straight duct in the engine exhaust system, due to lower temperature values in the hot section of the engine (Gawron and Białecki 2015), and such a modification allows to obtain a thrust with a maximum 
value of ca. $70 \mathrm{~N}$. The research in this paper was conducted with pneumatic start-up and the use of a straight duct in the exhaust system.

It is worth stressing that in the case of studies conducted with the use of miniature turbojet engines, bearing lubrication is executed mostly in an open system, through adding oil to the fuel. Oil added to the fuel adversely affects the assessment of the combustion process through contamination of the results due to the presence of oil, especially in the scope of emission of gas components of exhaust gases (Baranski et al. 2011). In the case of the presented rig, this problem was solved by a modification including the division of the fuel supply system into two different systems: a primary one, supplying fuel to the combustion chamber, and a secondary one, supplying fuel pre-mixed with oil to the bearings. This solution enables the supply of neat jet fuel to the combustion chamber.

\section{Tested fuels}

Conventional Jet A-1 fuel (obtained from a domestic refinery) and a blend of Jet A-1 with $48 \%$ of synthetic hydrocarbons obtained from HEFA process were used to supply the engine during the tests. Camelina vegetable oil was the raw material of the component produced according to the above-mentioned technology. It is worth emphasizing that a component of a HEFA production process is approved for use in engines and aircrafts. The tested fossil fuel meets the requirements of ASTM D1655-15d (1959), while the neat sustainable HEFA component complies with the standards of ASTM D7566-16 (2009). The blend of Jet A-1 with $48 \%$ HEFA component was marked in this article as HEFA fuel.

Selected physical and chemical properties of the tested fuels are presented in Table 1. The properties were selected to characterize the fuel scope of the fuel-air mixture creation and combustion process as well as to guarantee correct operating conditions of the fuel supply system.

The analysis of properties test fuel samples indicates that the HEFA fuel is characterized by a lower density and higher heat of combustion in relation to neat Jet A-1 fuel. As a consequence, it impacts the parameters associated with engine performance during the execution of engine tests. Higher viscosity was also identified, which may contribute to the formation of bigger droplets during the combustion process. A lower content of aromatics in the HEFA fuel results in a smaller tendency to carbon deposition and smoking during combustion. On the other hand, low aromatics content may increase the risk of damage to the engine sealing.

\section{Procedure and test conditions}

Test rig experiments were conducted according to the methodology described by Gawron and Białecki 2016. The profile of engine test refers to the selected operating modes of a turbojet engine. Operating times at specific rotational speeds have been chosen in such a way, as to obtain stability of the measured parameters, mainly in terms of exhaust gas emissions.

Experiments according to an engine test sample were executed for each tested fuel twice. Within the scope of every individual test, the analysed parameters were averaged in selected sets of measurement data, characterized by small values of standard deviations. The results from the last $30 \mathrm{~s}$ of the run (stabilization of measured parameters) on a given engine operating mode were adopted as the sets of measurement data. Next, the results for a given parameter from two independent tests for a given fuel were averaged. The average value of each parameter was supplemented with a maximum and minimum value, which correspond the average values from single engine run.

All engine tests were executed within the same day, so as to ensure the highest stability of ambient conditions as possible (Table 2). It is known that changes of the ambient conditions impact both the engine performance and the character of combustion products emissions.

\section{Results and discussion}

Comparative results for the tested fuels, in terms of their impact on the measured engine operating parameters, are presented in Fig. 1. In the case of fuel consumption, and thus, thrust-specific fuel consumption, the analysis for the speed of $39000 \mathrm{rpm}$ was omitted due to problems resulting

Table 1 Selected results of properties Jet A-1 and HEFA fuel

\begin{tabular}{lllcc}
\hline Property & Test method & Limits ASTM D1655-15d (1959)/D7566-16 (2009) & Results & Jet A-1 \\
\hline Density in $15{ }^{\circ} \mathrm{C}$ & & & HEFA fuel \\
Viscosity in $-20{ }^{\circ} \mathrm{C}$ & $\mathrm{kg} / \mathrm{m}^{3}$ & $775.0 / 840.0$ & 788.0 & 779.9 \\
Heat of combustion & $\mathrm{mJ} / \mathrm{kg}$ & Max 8.000 & 2.992 & 5.004 \\
Aromatics & $\%(\mathrm{~V} / \mathrm{V})$ & Min 42.80 & 43.45 & 43.70 \\
\hline
\end{tabular}


Table 2 Ambient test conditions

\begin{tabular}{lllll}
\hline Fuel & Test no. & $P_{\mathrm{o}}(\mathrm{bar})$ & $\mathrm{T}_{\mathrm{o}}\left({ }^{\circ} \mathrm{C}\right)$ & $\mathrm{RH}(\%)$ \\
\hline \multirow{2}{*}{ Jet A-1 } & Test 1 & 1016.5 & 12.6 & 22.2 \\
& Test 2 & 1015.9 & - & - \\
\multirow{2}{*}{ HEFA fuel } & Test 1 & 1018.1 & 14.5 & 22.4 \\
& Test 2 & 1018.0 & 12.3 & 25.6 \\
\hline
\end{tabular}
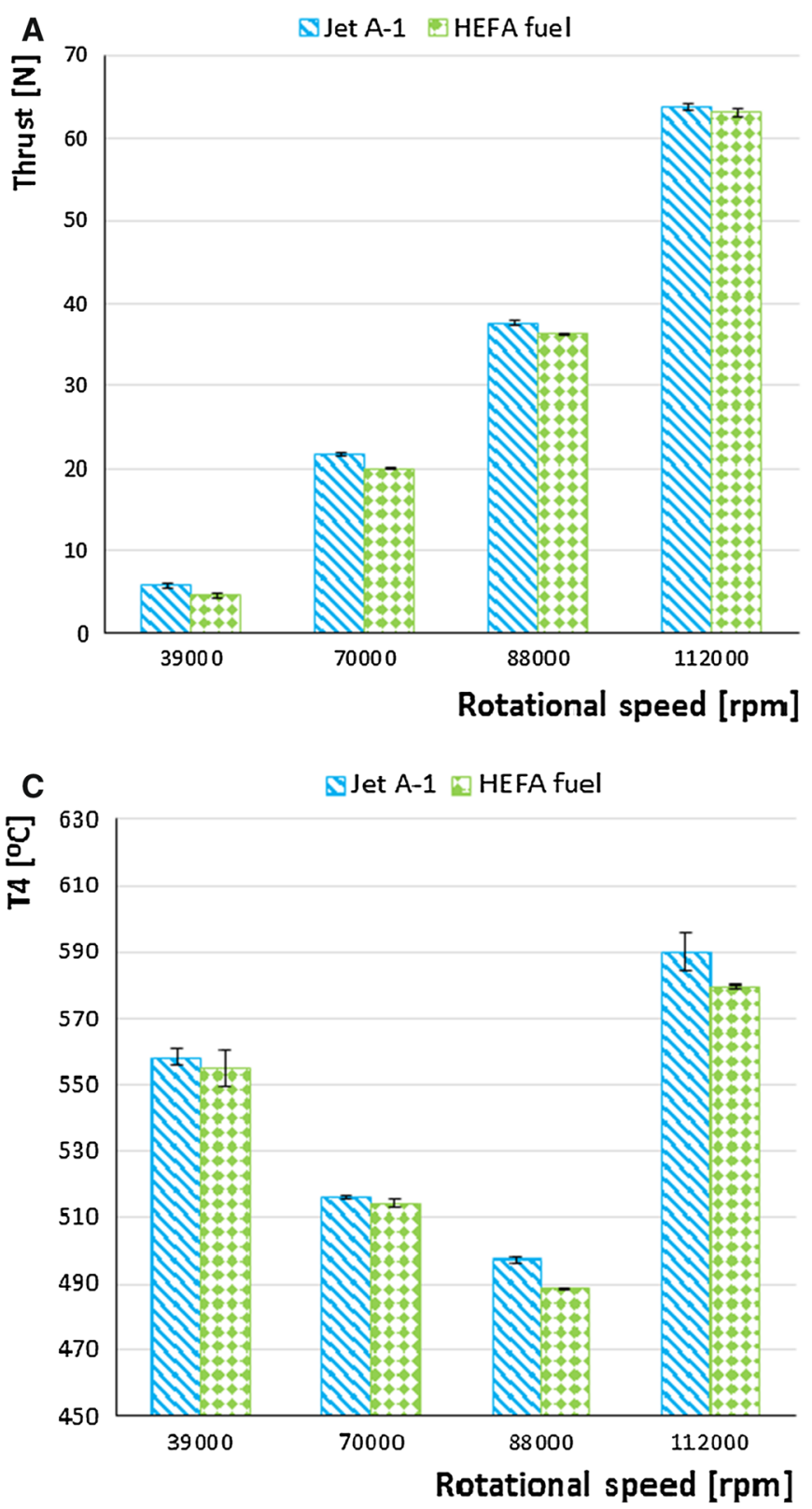

from the measurement of the fuel flow in the initial operating range of an appropriate sensor.

Figure 2 presents relative changes of operating parameters of a HEFA fuel fed engine in relation to neat Jet A-1 fuel.

Initially, the engine performance data showed a reduction in the fuel consumption in all analysed engine operating modes for the HEFA fuel in relation to Jet A-1. The
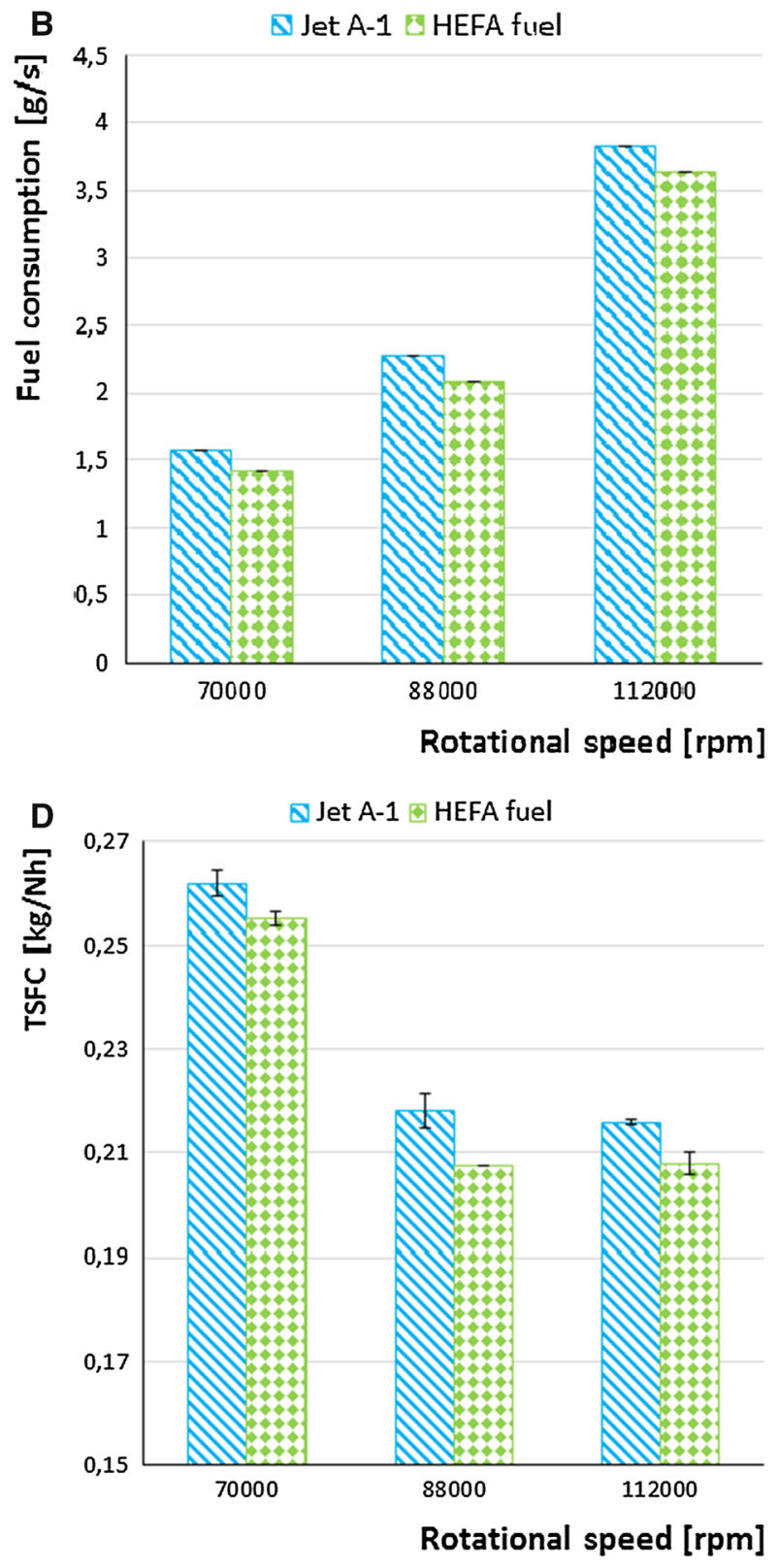

Fig. 1 Selected engine parameters as a function of rotational speed. a thrust, $\mathbf{b}$ fuel consumption, $\mathbf{c}$ turbine temperature, $\mathbf{d}$ thrust-specific fuel consumptions 


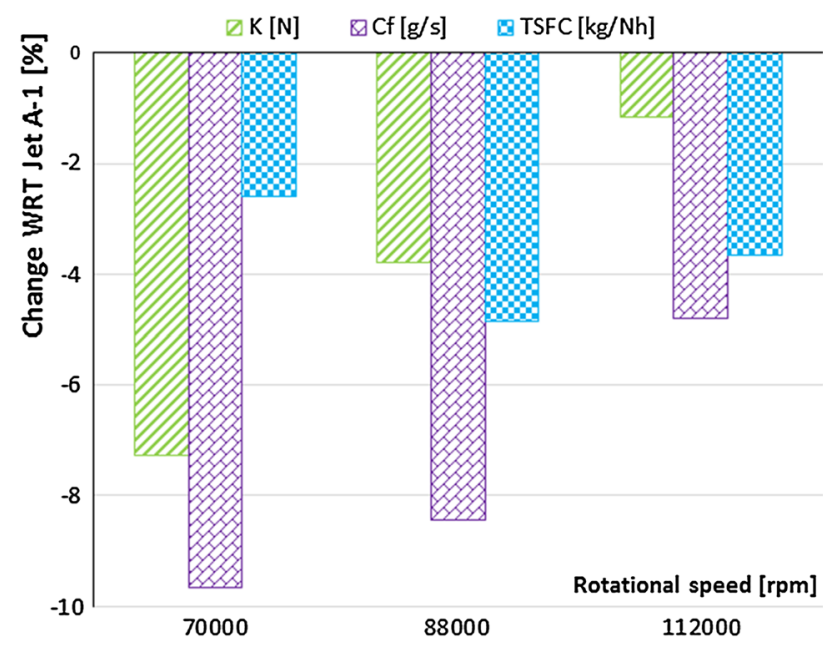

Fig. 2 Changes of engine performance with regard to Jet A-1

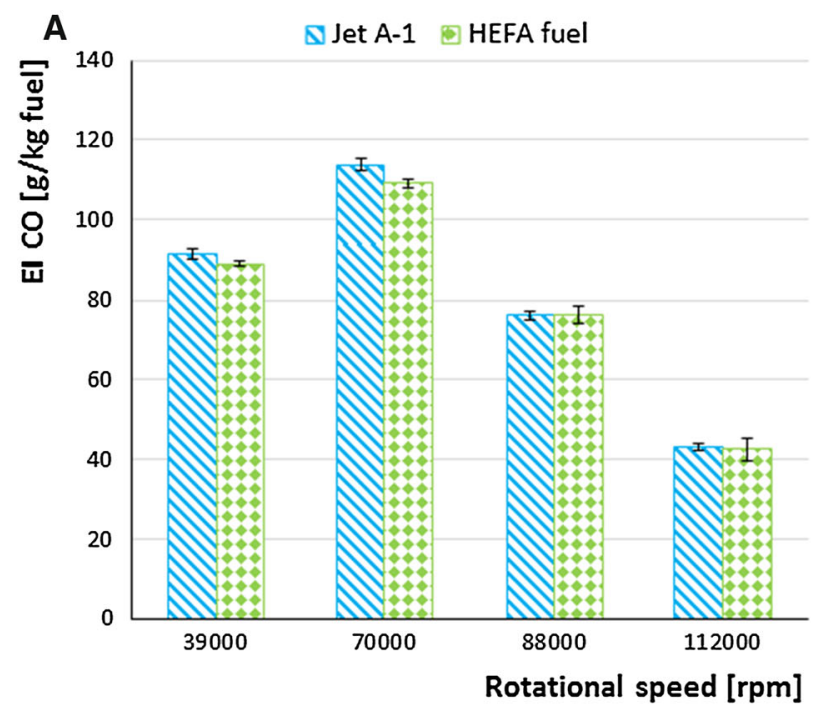

biggest difference for that parameter between the tested fuels was about $10 \%$. The thrust of a HEFA fuelled engine was smaller than for the Jet A-1 fuel. However, more significant changes were obtained in the fuel consumption values, which, hence, had ultimately impacted the obtained smaller thrust-specific fuel consumptions (TSFC) values for the HEFA fuel. The lower fuel consumption values obtained for the HEFA fuel are directly associated with a higher heat of combustion and, at the same time, lower density for the HEFA fuel compared to Jet A-1. The biggest differences in the fuel consumption between the tested fuels are visible for low operating modes of the engine, while, together with increasing rotation speed, they are getting smaller. Negligible changes are observed for the temperature value measured downstream of the turbine.
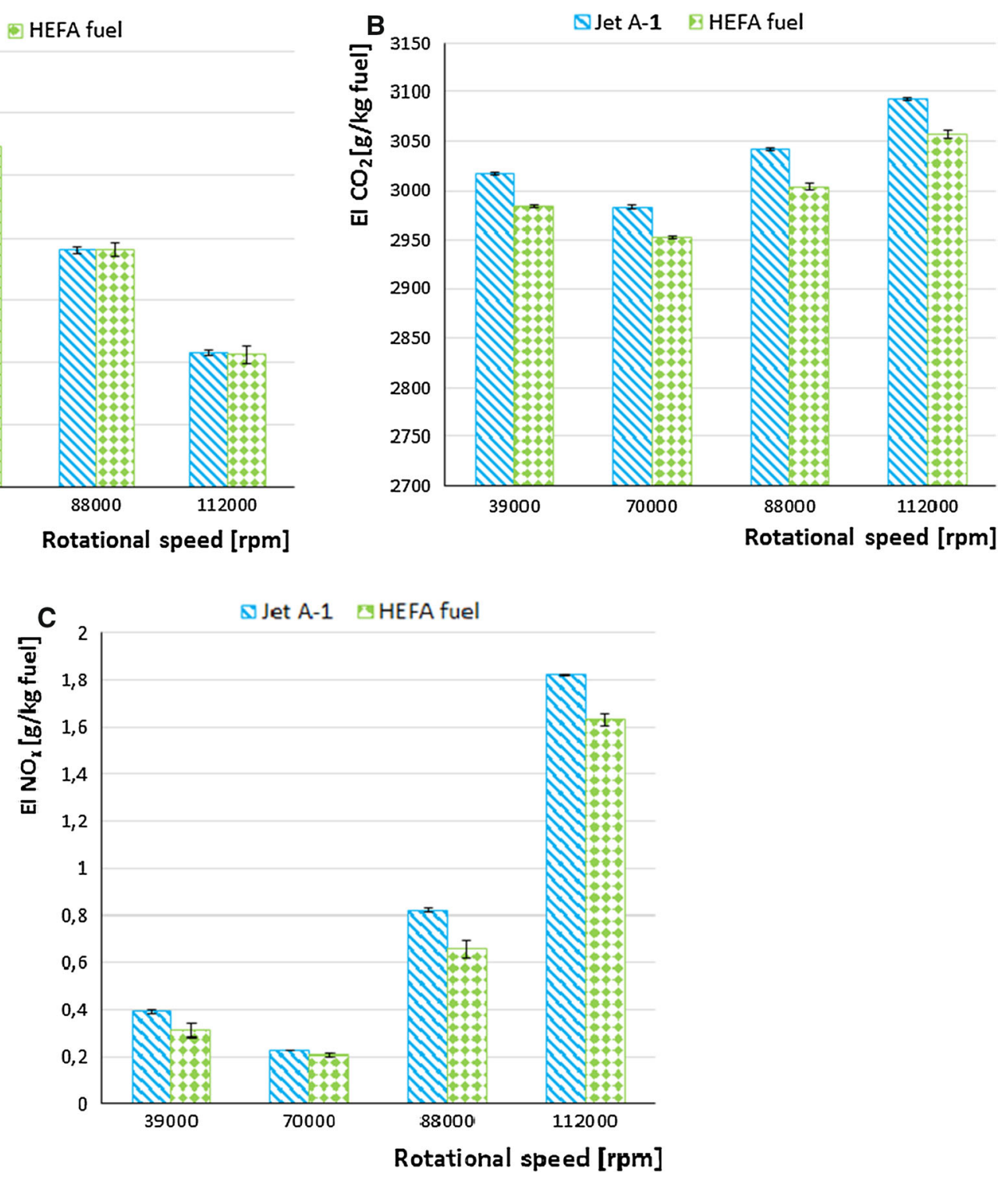

Fig. 3 Selected emission index as a function of rotational speed. a EI CO, b EI $\mathrm{CO}_{2}$, c EI $\mathrm{NO}_{x}$ 


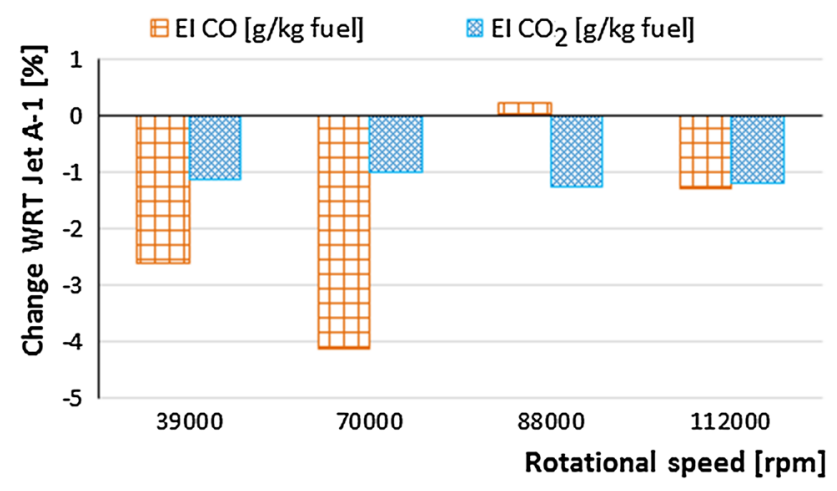

Fig. 4 Changes of EI $\mathrm{CO}$ and $\mathrm{EI} \mathrm{CO}_{2}$ with regard to Jet A-1

Comparative results for the tested fuels in terms of their impact on the emissions of selected gas componentscarbon monoxide $(\mathrm{CO})$, carbon dioxide $\left(\mathrm{CO}_{2}\right)$ and nitrogen oxides $\left(\mathrm{NO}_{x}\right)$-are presented in Fig. 3. The data were converted from the value of parameters measured in $\mathrm{ppm}$ or $\%$ to emission indices expressed in $\mathrm{g} / \mathrm{kg}$ of fuel.

The acquired results allow us to formulate a general conclusion that the emission index values for selected gas components of flue gases are lower for the HEFA fuel when compared to Jet A-1. In the case of an analysis conducted for $\mathrm{NO}_{x}$ and $\mathrm{CO}_{2}$, the differences in emissions of these compounds for all analysed engine operating conditions do not fall in the scope of statistical data analysis for the tested fuels. It is similar in the case of $\mathrm{CO}$ analysis for the speeds of 39000 and 70000 . On the other hand, in the case of the CO analysis for the speeds of 88 000 and $112000 \mathrm{rpm}$, the obtained differences between the fuels fall within the scope of statistical data analysis.

Figure 4 shows relative changes of $\mathrm{CO}$ and $\mathrm{CO}_{2}$ emissions index (EI) for the HEFA fuel in relation to neat Jet A-1 fuel. The $\mathrm{CO}_{2}$ emission in the case of HEFA fuel is smaller by ca. $1 \%$ for all of the analysed engine operating modes in comparison with the results for neat Jet A-1 fuel. In the case of $\mathrm{CO}$ emissions, the biggest relative change between the fuels was obtained for a rotational speed of 70 $000 \mathrm{rpm}$ - ca. $4 \%$.

The relative changes of $\mathrm{EI} \mathrm{NO}_{x}$ between tested fuels are not shown. This analysis was omitted because measurement results of $\mathrm{NO}_{x}$ from engine test runs were within the range of small concentrations (ca. dozen ppm). For such small values, the results may be misinterpreted.

\section{Conclusion}

The performance and emission characteristics of a miniature turbojet engine using a Jet A-1/HEFA blend were studied. HEFA is currently one of five paths of synthetic hydrocarbon production, certified and approved by the ASTM standard for use as a synthetic blending component in aviation turbine fuels. The presented results for this blend are compared with their corresponding values for the neat Jet A-1 fuel. The tests were carried out according to a determined engine test profile, which characterizes various operating modes of a miniature jet engine. The biggest differences in terms of operating parameters were achieved in fuel consumption. It was concluded that this parameter and individual fuel consumption are smaller for a Jet A-1/ HEFA bland than in the case of the Jet A-1 fuel. Emission indices of selected components of exhaust gases: $\mathrm{CO}, \mathrm{CO}_{2}$ and $\mathrm{NO}_{x}$ are also smaller compared with Jet A-1. In the process of reviewing the literature, it can be concluded that there are very few papers utilizing small-scale engines in the scope of testing alternative jet fuels. This paper confirms the usefulness of such a research tool in studies of such type, especially as a complementation of tests performed on full-scale aircraft engines.

Acknowledgements The authors would like to thank the Ministry of Science and Higher Education for the project financed within the framework of the statutory activity (Decision No 4111/E-282/S/ 2016), which covered the execution of the research presented in this paper.

\section{Compliance with ethical standards}

Conflict of interest The authors have declared no conflict of interest.

Open Access This article is distributed under the terms of the Creative Commons Attribution 4.0 International License (http:// creativecommons.org/licenses/by/4.0/), which permits unrestricted use, distribution, and reproduction in any medium, provided you give appropriate credit to the original author(s) and the source, provide a link to the Creative Commons license, and indicate if changes were made.

\section{Abbreviations}

ASTM American standard for testing and materials Biofuel Alternative fuel obtained from renewable feedstock

$C_{\mathrm{f}} \quad$ Fuel consumption $(\mathrm{g} / \mathrm{s})$

$\mathrm{CO} \quad$ Carbon monoxide

$\mathrm{CO}_{2} \quad$ Carbon dioxide

EI Emission index ( $\mathrm{g} / \mathrm{kg}$ fuel)

GTL Gas to liquid

HEF Hydroprocessed esters and fatty acids

HEFA fuel Blend 48\% HEFA with 52\% Jet A-1

HRJ Hydroprocessed renewable jet (also known as HEFA)

Jet A-1 Conventional (fossil) jet fuel

$K \quad$ Thrust of engine $(\mathrm{N})$

MiniJETRig Miniature jet engine test rig

$\mathrm{NO}_{x} \quad$ Nitrogen oxides 
$P_{\mathrm{o}} \quad$ Ambient pressure (bar)

RH Relative humidity (\%)

RPM Revolutions per minute

SAK Synthetic aromatic kerosene

SPK Synthesized paraffinic kerosene

$T_{\mathrm{o}} \quad$ Ambient temperature $\left({ }^{\circ} \mathrm{C}\right)$

$T_{4} \quad$ Turbine temperature $\left({ }^{\circ} \mathrm{C}\right)$

TSFC Thrust-specific fuel consumptions (N/kg h)

\section{References}

Ali AHH, Nour M (2017) Performance and environmental impact of a turbojet engine fueled by blends of biodiesels. Int J Environ Sci Technol 14:1-10. doi:10.1007/s13762-016-1228-4

Andrei IC, Niculescu ML, Pricop MV, Cernat A (2016) Study of the turbojet engines as propulsion systems for the unmanned aerial vehicles. In: 18th international conference scientific research and education in the air force AFASES 2016. Brasov, Romania, 26-28 May. doi:10.19062/2247-3173.2016.18.1.15

ASTM D1655-15d (1959) Standard specification for aviation turbine fuels

ASTM D4054-14 (1981) Standard practice for qualification and approval of new aviation turbine fuels and fuel additives

ASTM D7566-16 (2009) Standard specification for aviation turbine fuel containing synthesized hydrocarbons

Badami M, Nuccio P, Signoretto A (2013) Experimental and numerical analysis of a small-scale turbojet engine. Energy Conversat Manag 76:225-233. doi:10.1016/j.enconman.2013.07. 043

Badami M, Nuccio P, Pastrone D, Signoretto A (2014) Performance of a small-scale turbojet engine fed with traditional and alternative fuels. Energy Convers Manag 82:219-228. doi:10. 1016/j.enconman.2014.03.026

Baranski JA, Hoke JL, Litke PJ, Schauer F (2011) Preliminary characterization of bio-fuels using a small scale gas turbine engine. In: 49th AIAA aerospace sciences meeting including the new horizons forum and aerospace exposition. Orlando, USA, 4-7 January

Benini E, Giacometti S (2007) Design, manufacturing and operation of a small turbojet-engine for research purposes. Appl Energy 84:1102-1116. doi:10.1016/j.apenergy.2007.05.006

Braun-Unkhoff M, Riedel U, Wahl C (2017) About the emissions of alternative jet fuels. CEAS Aeronaut J 8:167-180. doi:10.1007/ s13272-016-0230-3

Buffi M, Chiaramonti D, Medina AV (2017) Strategies toward experimental assessments of new aviation renewable fuels and blends: the BIOREFLY project. Energy Procedia 105:433-438. doi:10.1016/j.egypro.2017.03.337

Canteenwalla P, Davison CR, Chishty WA, Ginestra C, Dally B (2016) Testing of synthesized aromatic kerosene (SAK) aviation fuel blends at simulated altitudes.In: ASME Turbo Expo. Seoul, South Korea, 13-17 June

Cavarzere A, Morini M, Pinelli M, Spina PR, Vaccari A, Venturini M (2014) Experimental analysis of a micro gas turbine fuelled with vegetable oils from energy crops. Energy Procedia 45:91-100. doi:10.1016/j.egypro.2014.01.011

Chiaramonti D, Rizzo AM, Spadi A, Prussi M, Riccio G, Martelli F (2013) Exhaust emissions from liquid fuel micro gas turbine fed with diesel oil, biodiesel and vegetable oil. Appl Energy 101:349-356. doi:10.1016/j.apenergy.2012.01.066

Chiariello F, Allouis C, Reale F, Massoli P (2014) Gaseous and particulate emissions of a micro gas turbine fuelled by straight vegetable oil-kerosene blends. Exp Thermal Fluid Sci 56:16-22. doi:10.1016/j.expthermflusci.2013.11.013

Chishty W, Davison C, Bird J, Chan T, Cuddihy K, McCurdy M, Barton P, Krasteva A, Poitras P (2011) Emissions assessment of alternative aviation fuel at simulated altitudes. In: ASME Turbo Expo. Vancouver, USA, 6-10 June

Coban K, Şöhret Y, Colpan CO, Karakoç TH (2017) Exergetic and exergoeconomic assessment of a small-scale turbojet fuelled with biodiesel. Energy. doi:10.1016/j.energy.2017.05.096

Dutczak J (2016) Micro turbine engines for drones propulsion. In: Scientific conference on automotive vehicles and combustion engines KONMOT 2016. Cracow, Poland, 22-23 September. doi:10.1088/1757-899X/148/1/012063

Gaspar RMP, Sousa JMM (2016) Impact of alternative fuels on the operational and environmental performance of a small turbofan engine. Energy Convers Manag 130:81-90. doi:10.1016/j. enconman.2016.10.042

Gawron B, Białecki T (2015) The laboratory test rig with miniature jet engine to research aviation fuels combustion process. J KONBIN 36:79-90. doi:10.1515/jok-2015-0058

Gawron B, Białecki T (2016) Measurement of exhaust gas emissions from miniature turbojet engine. Combust Eng 167:58-63. doi:10. 19206/CE-2016-406

Gawron B, Białecki T, Dzięgielewski W, Kaźmierczak U (2016) Performance and emission characteristic of miniature turbojet engine fed Jet A-1/alcohol blend. J KONES 23:123-129. doi:10. $5604 / 12314005.1213540$

Gutierrez-Antonio C, Gomez-Castro FI, de Lira-Flores JA, Hernandez $S$ (2017) A review on the production processes of renewable jet fuel. Renew Sustain Energy Rev 79:709-729. doi:10.1016/j.rser. 2017.05.108

Habib Z, Parthasarathy R, Gollahalli S (2010) Performance and emission characteristic of biofuel in a small-scale gas turbine engine. Appl Energy 87:1701-1709. doi:10.1016/j.apenergy. 2009.10.024

Hari TK, Yaakob Z, Binitha NN (2015) Aviation biofuel from renewable resources: routes, opportunities and challenges. Renew Sustain Energy Rev 42:1234-1244. doi:10.1016/j.rser. 2014.10.095

Hoxie A, Anderson M (2017) Evaluating high volume blends of vegetable oil in micro-gas turbine engines. Renew Energy 101:886-893. doi:10.1016/j.renene.2016.09.054

Ibrahim MN, Ali AHH, Ookawara S (2013) Performance assessment of turbojet engine operated with alternative biodiesel. In: ASME 2013 power conference. Boston, USA, 29 July-1 August. doi:10. 1115/POWER2013-98183

Mendez CJ, Parthasatathy RN, Gollahalli SR (2014) Performance and emission characteristic of butanol/Jet $\mathrm{A}$ blends in a gas turbine engine. Appl Energy 118:135-140. doi:10.1016/j.apenergy.2013. 12.011

Nkoi B, Pilidis P, Nikolaidis T (2013) Performance of small-scale aero-derivative industrial gas turbines derived from helicopter engines. Propuls Power Res 2(4):243-253. doi:10.1016/j.jppr. 2013.11.001

Şöhret Y, N Kaya, Özerdem MB, Karakoç TH (2015) Contribution of alternative fuels to aircraft exhaust gas emission reduction. In: 7th international exergy, energy and environment symposium IEEES'7. Valenciennes, France 27-30 April 
Velarde C (2015) Initiative towards sustainable kerosene for aviation-ITAKA project. In: IATA 2015 report on alternative fuels, p 25-27. https://www.iata.org/publications/Documents/ 2015-report-alternative-fuels.pdf
Zhang C, Hui X, Lin Y, Sung CJ (2016) Recent development in studies of alternative jet fuel Combustion: progress, challenges, and opportunities. Renew Sustain Energy Rev 54:120-138. doi:10.1016/j.rser.2015.09.056 